\title{
Parafraza jako środek polemiczny w dyskusji eucharystycznej w „Trajedyi o Mszej" (1560) Bernardina Ochina ${ }^{1}$
}

\author{
Wojciech Kordyzon \\ Uniwersytet Warszawski \\ wojciech.kordyzon@uw.edu.pl (D) https://orcid.org/0000-0002-4291-886X
}

Trajedyja o Mszej pióra włoskiego teologa Bernardina Ochina ukazała się w 1560 roku w pińczowskiej oficynie Daniela z Łęczycy, pracującego wówczas dla tamtejszego zboru ewangelickiego ${ }^{2}$. Wydany w Polsce utwór nie jest dosłownym przekładem wersji łacińskiej i włoskiej, znanych jedynie z wydań późniejszych niż polskie (z 1563 roku) ${ }^{3}$. Choć skala ingerencji nieznanego autora spolszczenia w samą materię tekstową nie jest znaczna, to dokonał on istotnych zmian kompozycyjnych, układając wersję polską w rozpisaną na dwa akty tragedię, na którą składa się kilka komponentów potencjalnego pierwowzoru. Zabieg ten wskazuje po części na cel wydawców polskich, ponieważ poskutkował podporządkowaniem hybrydycznego oryginału pojedynczej formie literackiej. W efekcie Trajedyja o Mszej stała się utworem o wyraźnych cechach polemicznych (ponieważ przeciwstawia się przyjętym przez tradycję rzymską konceptualizacjom mszy), perswazyjnych (adresowana jest bowiem do wszystkich chrześcijan i wyraża nadzieję wydawców na przekonanie do ewangelickiego rozumienia kwestii mszy i Eucharystii) i edukacyjnych (ze względu na próbę ukazania abstrakcyjnych problemów teologicznych za pomocą dramatycznie ujętej fabuły, która pozwolić ma na zrozumienie charakteru stanowiska protestanckiego).

1 Praca naukowa finansowana ze środków budżetowych na naukę w latach 2017-2021 jako projekt badawczy w ramach programu „Diamentowy Grant”.

2 B. Ochino, Trajedyja o Mszej, z której każdy snadnie wyrozumieć może początek i wszelaka jej sprawę, i co prawdziwej Wieczerzej Pańskiej właśnie każdy wiedzieć ma, Pińczów 1560.

3 Na temat relacji między tekstem polskim a potencjalnym pierwowzorem (najpewniej włoskim w zgodzie z deklaracją $\mathrm{w}$ dedykacji umieszczonej w polskim wydaniu) zob. J. Ślaski, $L e$ „Tragedie” di Bernardino Ochino in polacco, [w:] Movimenti ereticali in Italia e in Polonia nei secoli XVI-XVII. Atti del Convegno italopolacco, Firenze, 22-24 settembre 1971, Firenze 1974, s. 103-117; J. Kleiner, „Tragedye” Ochina, „Pamiętnik Literacki” 1910, t. 9, z. 4, s. 397-418. 
Celem artykułu jest omówienie sposobów wykorzystywania biblijnych słów Chrystusa „Hoc est corpus meum” (Mt 26, 26; Mk 14, 22; Łk 22, 19; 1 Kor 11, 24) w spolszczonym utworze Ochina. Przeanalizowane zostaną metody i warunki ich wprowadzania do tekstu. Owa biblijna fraza przejawia się w utworze w dwóch konwencjach: dokładniejszego przytoczenia oraz swobodniejszej parafrazy mającej oddawać sugerowany sens. Rozpoznanie charakteru tych tekstualnych zabiegów pozwoli na wskazanie, w jaki sposób redaktor polskiego wydania wyzyskuje cytaty biblijne w utworze o polemiczno-edukacyjnym charakterze, a także jaki stosunek interpretatorów do Pisma wynika z zaobserwowanych praktyk przytaczania i parafrazowania. Proponowane spojrzenie ma więc na celu nie tyle przybliżenie stanowiska w kwestiach eucharystycznych czy sakramentologicznych, ile wskazanie na tworzywo literackie, w którym te przekonania są wyrażane, w szczególności zaś zabieg parafrazy tekstu biblijnego służący uwypukleniu przekonań teologicznych, prowadzeniu dyskusji oraz zbijaniu argumentów oponentów.

Trajedyja o Mszej dzieli się na dwa akty. Pierwszy ma literacki charakter tragiczny, zawiera uporządkowane sekwencje wydarzeń. Służy ukazaniu genezy Mszy, a występują w nim liczne personifikacje uwikłane w dzieje uosobionej ceremonii: jej poczęcia w ramach planu Szatana, narodzin z łona Kościoła Rzymskiego (tzn. żeńskiej Eklezji), wychowania przez Mądrość Ludzką i wreszcie konfliktu z „prawą córką Chrystusa”, Wieczerzą Pańską, która pod koniec części wtrącona zostaje przez bezimiennego Papieża, ojca Mszy, do karceru. Akt drugi traci akcję dramatyczną na rzecz struktury dialogowej opartej na konwencji procesu ${ }^{4}$. W tej części bliżej nieznany Miłośnik Chwały Bożej pozywa Mszę za ukrywanie przed chrześcijanami prawdy o Wieczerzy Pańskiej. Sędzią w tym sporze jest Duch Święty, Msza zaś jako kobieta - zgodnie z dawnymi zwyczajami procesowymi - nie może bronić się samodzielnie, zaś jej adwokatem zostaje spersonifikowany Zabobon. Prymarna konwencja procesowa polega na dyskusji pomiędzy oskarżycielem (Miłośnikiem) a obroną (Zabobonem), mediowanej przez Ducha Świętego sprawującego pieczę nad sądową batalią i zarządzającego jej kolejne sesje. Zarazem ogólniejszym schematem, do którego nawiązuje utwór w tej części, pozostaje rozpowszechniona

4 O źródłach tego motywu wykorzystanych przez autora zob. W. Kordyzon, Msza przed trybunatem. Personifikacja Mszy w spolszczonym dialogu Bernardina Ochina na tle europejskiej literatury reformacyjnej pierwszej połowy XVI wieku, „Terminus” 21 (2019) z. 2, s. 215-244, http://dx.doi.org/ 10.4467/20843844TE.19.017.11191. 
w praktyce nowożytnej polemiki religijnej formuła dysputacji ${ }^{5}$. Miłośnik występujący jako stawiający tezy proponens ściera się z Zabobonem działającym w tekście jako opponens. Co istotne, podobnie jak w konwencji dysputacyjnej, przedmiotem dyskusji obu stron są argumenty zaczerpnięte z Pisma Świętego, wśród których kluczową rolę odgrywają słowa będące obiektem analizy w niniejszym artykule, dotykają bowiem nie tylko aspektów związanych z celebracją mszy, ale i jej wymiarem sakramentalnym, którego dotyka istota tez stawianych przez reformatorów z kręgu szwajcarskiego.

Należy podkreślić, że ówczesna dyskusja eucharystyczna była ściśle powiązana z toczącą się w środowisku protestanckim debatą o ceremoniale liturgii (w ówczesnej polszczyźnie określanej „,eremoniją”, „porządkami kościelnymi”, „rituales”, „posługą” itd.) ${ }^{6}$, rozumianym jako zewnętrzny przejaw kultu. Źródłem obu dyskusji była debata między obozami Marcina Lutra i Ulricha Zwinglego toczona w latach 1525-1529, która przypieczętowała rozłam na bardziej pojednawcze stanowisko reformatora z Wittenbergi i symboliczne rozumienie słów „hoc est corpus meum” (z est rozumianym w znaczeniu significat), przy którym obstawali Szwajcarzy ${ }^{7}$. W tym sensie zmiany teologiczne musiały być powiązane z widoczną formą, jaką przydawano ceremonii zbudowanej wokół tej frazy.

Sam Ochino związany był w tym okresie z Zurychem, gdzie dominującą pozycję w sprawach teologicznych miał Heinrich Bullinger, rozwijający wcześniejsze koncepcje Zwinglego. W owym czasie, jeszcze sprzed epoki konfesjonalizacji znacząco usztywniającej doktryny, nie jest niczym zaskakującym, że zleceniodawcą przekładu i nakładcą polskiego wydania był Francesca Lismanino, ówczesny superindendent ewangelickiego zboru małopolskiego w Pińczowie, prowadzący intensywną korespondencję tak z kręgiem zuryskim, jak i Genewą ${ }^{8}$. Spolszczony tekst Ochina dotyka jednak problemów potencjal-

5 Na temat dysputacji zob. M. Ryszka-Kurczab, „Aby każdy miłośnik prawdy onej szukając, z czytania jej dojść mógl”. Sposoby uwiarygodniania przekazu w szesnastowiecznych relacjach z polskich dysput wyznaniowych, „Terminus” 20 (2018) z. 2, s. 165-193, http://dx.doi.org/10.4467/20843844 TE.18.006.9751.

6 Zob. I. Winiarska-Górska, Zagadnienie ceremonii w szesnasto- $i$ siedemnastowiecznym piśmiennictwie religijnym protestantów jako spór o język sakralny, „Napis” 16 (2010), s. 65-67.

7 Nt. genezy, przebiegu i najbliższych w czasie konsewkencji tego sporu dla podziałów wewnątrz obozu reformacyjnego zob. A. Nelson Burnett, Karlstadt and the Origins of Eucharistic Controversy. A Study in the Circulation of Ideas, New York-Oxford 2011, http://dx.doi.org/10.1093/acprof:oso/ 9780199753994.001.0001.

8 Zob. np. T. Wotschke, Der Briefweschsel der Schweizer mit den Polen, Leipzig 1908. 
nie różnicujących stosunek tych dwu środowisk do Wieczerzy Pańskiej jedynie do pewnego stopnia, o czym dalej. Kluczowe zagadnienia związane z obecnością Chrystusa w sakramencie oraz kwestią ofiary Chrystusa w Mszy postrzegane są w zbliżony sposób i przez reformatorów szwajcarskich, i Ochina wraz z jego tłumaczem. Zwraca jednak uwagę dość istotne dążenie w stronę akcentowania symbolizmu eucharystii, nieco mniej kompromisowe niż tezy zawarte w zgodzie zuryskiej (Consensus Tigurinus) z 1549 roku$^{9}$.

Niewykluczone, że ta własność utworu Ochina wyzyskana została przez polskiego wydawcę. List dedykacyjny sygnowany inicjałami Lismanina wieńczy data 6 lutego 1560 roku, w kolofonie druku znajduje się zaś informacja, że książka wyszła spod pras pińczowskiego typografa Daniela z Łęczycy niecałe dwa miesiące później - 11 kwietnia. Raptem kilka tygodni przed spisaniem dedykacji 8 stycznia zmarł w Pińczowie Jan Łaski, z którego działalnością reformatorską i organizacyjną zbór małopolski wiązał duże nadzieje. Lismanino, podówczas wspólnie z Łaskim nadający ton działalności tamtejszego Kościoła ewangelickiego, pozostał więc osamotniony na polu polemicznej walki zarówno z obozem katolickim, jak i wobec problemów wewnątrzzborowych (tj. kontrowersji związanych poglądami Francesca Stancara, jak i coraz wyrazistszej frakcji trydeistycznej) ${ }^{\mathbf{1 0}}$, z którymi musiał się mierzyć. Halina Kowalska zauważyła, że wiele działań Lismanina bezpośrednio po śmierci Łaskiego nastawionych było na umocnienie Kościoła małopolskiego wobec aktorów zewnętrznych, częściowo poprzez odpowiedni dobór publikowanych w Pińczowie tekstów ${ }^{11}$. Należały do nich mowy pogrzebowe na cześć zmarłego reformatora spisane przez Piotra Statoriusa i Abla Sylviusa (Jakuba Sylwiusza), wydane pod protekcją i zapewne staraniem Lismanina ${ }^{12}$. Wiadomo, że Włoch niektóre z egzemplarzy zaopatrywał ponadto w własnoręczne dedykacje

9 Nt. uwarunkowań zgody zuryskiej zob. A. Nelson Burnett, From concord to confession: the Wittenberg Concord and the Consensus Tigurinus in historical perspective, „Reformation \& Renaissance Review” 18 (2016) z. 1, s. 47-58, https://doi.org/10.1080/14622459.2016.1157347.

10 Zob. Z. Ogonowski, Socynianizm. Dzieje, pogladdy, oddziaływanie, Warszawa 2015, s. 59-61; D. Caccamo, Eretici italiani in Moravia, Polonia, Transilvania 1558-1611. Studi e documenti, Firenze 1970, s. 21-22.

11 H. Kowalska, Działalność reformatorska Jana Easkiego w Polsce 1556-1560, Warszawa 1999, s. 150. Idzie o następujące mowy: P. Statorius, In clarissimi viri d[omini] Ioannis a Lasko Poloniae baronis obitum funebris oratio, Pinczoaviae 1560; A. Silvius, Oratio funebris in obitum praeclarissimi viri et veare religionis vindicis invictissimi, Domini Ioannis a Lasco, Pinczoviae 1560 (non vidi). Silvius we wstępie tłumaczył się, że mowę - mimo opublikowania już utworu Statoriusa - napisał i dał wydrukować, ulegając namowom Lismanina (zob. K. Estreicher, Bibliografia polska, t. 28, Kraków 1930, s. 98). 
i rozsyłał, co wskazywałoby na świadome podjęcie działań komunikacyjnych poza zgromadzenie ${ }^{13}$. Już na początku lutego 1560 roku ukazała się także odpowiedź na dialogi Marcina Kromera sporządzona przez Statoriusa (lub też, jak sądzi Kowalska, wspólnym wysiłkiem przez pińczowskich ministrów), w której rozprawia się także z zarzutami katolickiego duchownego wobec Łaskiego ${ }^{14}$. Trajedyję o Mszej można by widzieć jako element tej kampanii wydawniczej, mającej na celu utrzymanie doktrynalnego stanowiska Łaskiego. Odegrało ono pewną rolę w ciągnących się od kilku lat trudnych negocjacjach między Małopolanami a Jednotą Czeskobraterską w sprawie ewentualnej unii, od synodu w Koźminku (1555), poprzez fiasko kolokwium lipnickiego na Morawach (1558). Choć z początku Łaski starał się nie uwypuklać różnic, ostatecznie nie zgodził się na ustępstwa w tej kwestii. Gest Lismanina publikującego tekst uwyraźniający stanowisko eucharystyczne ze strony Małopolan, istotnie różniących się $\mathrm{w}$ tym punkcie z braćmi czeskimi, mógł być zarazem próbą utrwalenia przyjętych w Pińczowie przekonań doktrynalnych i manifestacją trwania przy obranym stanowisku mimo śmierci jednego z najbardziej wpływowych teologów. Z tej próby sił oba zgromadzenia wyszły podzielone, gdyż jak wiadomo, unia nie została zawarta ani jako przedsięwzięcie włączające Jednotę do struktur małopolskich, ani nawet jako kompromisowa federacja obu Kościołów ${ }^{\mathbf{1 5}}$. Nie bez znaczenia mógł być również fakt, że w poprzedzającym wydanie Ochina roku ukazał się staraniem królewieckiego środowiska luterańskiego polski przekład Praktyki o mszy Valentina Wannera, w którym wyrażono charakterystyczne dla luteran umiarkowane stanowisko w kwestii konieczności uporządkowania i oczyszczenia pewnej części ceremoniału mszy (dopuszczając możliwość zachowania wielu jej elementów), jak i kompromisowe stanowisko w kwestiach teologicznych, np. nie formułując wprost czy msza stanowi ofiarę, czy też nie ${ }^{16}$. Szczegółowe różnice między

13 Zob. K. Estreicher, Bibliografia polska, t. 29, Kraków 1933, s. 226.

14 Zob. H. Kowalska, Działalność reformatorska Jana Easkiego w Polsce 1556-1560, dz. cyt., s. 151. Mowa o: P. Statorius, In duos Martini Cromeri dialogos, qui de vera et falsa nostri temporis religion inscribuntur animadversiones brevissimae, Pinczoviae 1560.

15 O końcowej fazie pertraktacji między zborem małopolskim a braćmi czeskimi zob. H. Gmiterek, Jan Łaski a unia Małopolan z braćmi czeskimi, [w:] Jan Łaski 1499-1560 w pięćsetlecie urodzin. Materiały konferencji zorganizowanej przez Instytut Historii PAN, Uniwersytet Warszawski oraz Konsystorz Kościoła Ewangelicko-Reformowanego w RP, red. W. Kriegseisen, P. Salwa, Warszawa 2001, s. 35-38.

16 V. Wanner, Praktyka o mszy, co o niej a jako rozumieć mamy, przeł. W. N[owomiejski], Królewiec 1559. 
tezami w przekładach Wannera i Ochina wymagałyby osobnego omówienia, choć należy zauważyć istotne podobieństwo konstrukcji tytułów obu publikacji. Pozwala to przypuszczać, że środowisko małopolskie mogło chcieć sprecyzować swoje poglądy w języku wernakularnym wobec drukowanej wypowiedzi konkurencyjnych luteran królewieckich.

Ustalenia w sprawie sposobu celebrowania Wieczerzy Pańskiej podjęte przez synod w Pińczowie w 1559 roku, w którym Łaski również uczestniczył, były pierwszą próbą Małopolan uporządkowania tych kwestii i miały raczej ogólny charakter ograniczający się do wskazania konieczności zachowania prostoty ceremonii, bez wnikania w szczegóły problematyki sakramentologicznej ${ }^{17}$. Warto jednak zauważyć, że Małopolanie - w przeciwieństwie do środowiska luterańskiego - uznali za niezbędne zdecydowane oczyszczenie ceremoniału eucharystycznego ze wszystkich rytualnych dodatków uznanych za zbytkowne i zanadto kojarzące się z papiestwem. Poglądy Łaskiego w tym zakresie znane są m.in. z londyńskiego Forma ac ratio z 1555 r. Reformator podkreślał w nim, że jeśli tylko rozważa się Wieczerzę nieco wnikliwiej, to wszystkie jej tajemnice ujawniają się wiernym w samej czynności przystępowania do niej ${ }^{18}$. Przede wszystkim jednak rozumiał łamanie chleba i wznoszenie kielicha w kategoriach symbolu i reprezentacji: „ukazują [one] symbolicznie mękę [...] Chrystusa”, „pokazują nam, zaświadczają i oznaczają, a także [...] widzialnie zwiastują, że Bóg jest jednocześnie Panem i Sędzią"19. Co charakterystyczne, pouczał także, że są one „symbolami naszego zjednoczenia z Chrystusem Panem w jego ciele [...] i w Jego krwi”"20, wskazując ponadto na udział Ducha Świętego w sakramencie, który ma pieczętować „umysły Boskim tchnieniem” i umacniać „ufność w Bożą obietnicą”. Pozostawał tym samym najbliżej ujęcia proponowanego przez Heinricha Bullingera, który dystansował się od Kalwinowego ujęcia roli Ducha Świętego w odniesieniu do medium sakramentu na rzecz podkreślenia Jego roli w stosunku do wiary („ufności”) ${ }^{21}$. Publikacja spolszczonego utworu Ochina przypada więc

17 Zob. Akta synodów różnowierczych, t. 1: 1550-1559, oprac. M. Sipayłło, Warszawa 1966, s. 301-303 (synod w Pińczowie, 13 czerwca 1559). Zob. także: H. Kowalska, Działalność reformatorska Jana Łaskiego w Polsce 1556-1560, dz. cyt., s. 138-140.

18 J. Łaski, Forma i całkowity porządek kościelnego posługiwania, przeł. T. Płóciennik, Warszawa 2004, s. 130.

19 Tamże.

20 Tamże, s. 132.

21 Zob. M. Allen, Sacraments in the Reformed and Anglican Reformation, w: The Oxford Handbook of Sacramental Theology, ed. by H. Boersma, M. Levering, Oxford 2018, s. 292, https://doi.org/10.1093/ 
na okres, gdy, po pierwsze, wspólnoty protestanckie w Królestwie Polskim i Wielkim Księstwie Litewskim nie zdefiniowały jeszcze precyzyjnie swojej liturgii ${ }^{22}$, po drugie zaś poddawana krytyce liturgia rzymska również nie miała jeszcze jednolitego charakteru, a brewiarz i mszał Piusa V miały zostać opublikowane dopiero po soborze trydenckim pod koniec dekady, w której pińczowianie wydrukowali Trajedyję $e^{23}$. Czynniki te sprawiły, że przedmiotem debaty w omawianym utworze jest w mniejszym stopniu sam ryt mszy (tj. jej części, układ, przypisywane im znaczenia), ile teologiczne podstawy liturgii oraz umotywowany tradycją ceremoniał rozumiany jako najbardziej zewnętrzny przejaw jej odprawiania.

W spolszczonej Trajedyi Ochina powstanie i rola Mszy - jako spersonifikowanej postaci przeciwstawionej Wieczerzy Pańskiej - wpisane zostało w przyczynowo-skutkową logikę właściwemu tragedii układu zdarzeń, co traktować można jako próbę obrazowego przepisania rozwoju abstrakcyjnej myśli teologicznej na działania konkretnych postaci uosabiających pojęcia i koncepcje. Dlatego krytyczny wobec rzymskiej formy ceremonii Ochino, przekonany o tym, że papiestwo jest królestwem Antychrysta, włożył zamysł powstania Mszy w usta Szatana:

Szatan: [...] Nadto jeszcze dla swej transsubstancyjacyjej, to jest dla swego przetworzenia chleba w ciało, stanie się między ludźmi przyczyną niezliczonych błędów [...]. A co nadnagorsze, iż rozłączy krześcijany od Krystusa [...] swymi zbytecznymi zabobony, wymysły a onym bałwochwalstwem, za którym się oni udadzą, iż będą chleb za Boga chwalić24.

Warto odnotować, że elementem owego zamysłu ma być właśnie przypisanie doktryny o transsubstancjacji siłom diabelskim - czynnikowi powodującemu konflikty w łonie chrześcijaństwa, a także prowadzącemu do szeroko rozumianego bałwochwalstwa. To założenie, zwerbalizowane czytelnikowi na początku utworu, będzie kluczowe dla sposobów sugerowanego w tekście rozumienia biblijnych słów Chrystusa dotyczących Eucharystii. Te również

oxfordhb/9780199659067.013.35.

22 Zob. D. Petkūnas, Holy Communion Rites in the Polish and Lithuanian Reformed Agendas of the 16th and Early 17th Centuries, Klaipèda 2007, s. 60-92.

23 Zob. P. Szczaniecki, Recepcja mszału rzymskiego w Polsce, [w:] tenże, Stużba Boża w dawnej Polsce, Poznań 1966, s. 129-137. Zob. także J. W. Boguniowski, Rozwój historyczny ksiąg liturgii rzymskiej do soboru trydenckiego i ich recepcja w Polsce, Kraków 2001, s. 194-197.

24 B. Ochino, Trajedyja o Mszej..., dz. cyt., k. F 4 v-r. 
pojawiają się już w pierwszym akcie, ale zostają przytoczone przez personifikację Mądrości Ludzkiej (a zatem negatywnej postaci), której rolą jest wychowanie i edukacja Mszy:

Mądrość Ludzka: Rozmyślam się też na to dobrze, wiedząc, iż Krystus oprócz wszelakiego dworstwa a przez wszech cerymonii ustawiał wieczerzą swoję nie w zbytku, ale w mierności. [...] A tak wiem to pewnie, iż Krystus Pan, siedząc u stołu z apostoły swymi, wziął chleb w ręce, jako piszą ewanjelistowie [...], a uczyniwszy dzięki Bogu Ojcu swemu, łamał i dawał im mówiąc: „Bierzcie a jedzcie, toć jest ciało moje, które za was będzie wydane. Czyńcie to na pamiątkę moję.” Także potym wziąwszy i kubek a podziękowawszy Bogu Ojcu, rzekł do nich: „Pijcie z tego wszyscy, tenci jest kielich testamentu nowego w mojej krwi, która będzie wylana na odpuszczenie grzechów wiela ludzi.” Tymi oto cerymonijami [...] sprawował Krystus Pan wieczerzą swoję z apostoły swoimi [...], co ja wszystko opak wywrócę a wynicuję ${ }^{25}$.

Zacytowana wypowiedź służy okazaniu czytelnikowi, że Mądrość Ludzka doskonale zna ewangeliczną genezę Eucharystii i świadomie planuje „wywrócenie opak” ładu ustanowionego przez Chrystusa, zaś edukowana przez nią Msza tę wiedzę przyjmuje. Za pomocą sceny przedstawiającej relację alegorycznych figur szesnastowieczny odbiorca poznać miał przyczynę krytyki ceremoniału mszy ze strony protestanckiej: stała się ona w tym ujęciu emanacją przedłożenia ludzkiego rozumu ponad ustanowiony przez Boga porządek.

Faktyczna dyskusja interpretacyjna o bardziej dialogowym charakterze eksponującym argumenty wytaczane przez obie strony ma jednak miejsce dopiero w akcie drugim. Dyskusja pomiędzy Miłośnikiem Chwały Bożej (reprezentującym przekonania, które można utożsamiać czy to z Ochinem, czy to ze środowiskiem małopolskich ewangelików) a Mszą i Zabobonem (oznaczającymi papiestwo i jego zwolenników) ma sprawiać wrażenie głęboko osadzonej w Piśmie, nawiązując tym samym do wspomnianej konwencji dysputacyjnej. Ważne jest jednak rozpoznanie, że cytaty biblijne rzadko są $\mathrm{w}$ tej debacie przywoływane in extenso. Nie powinno to dziwić, gdy weźmie się pod uwagę, że we wczesnonowożytnych pismach polemiczno-religijnych frazy biblijne niejednokrotnie przywodzone były bez odwołania do konkretnego przekładu, a nieraz, jak się przypuszcza, z pamięci lub tłumaczone ad hoc na polski z wersji łacińskich czy greckich. Zagadnienie to jest jednak dotąd dość 
słabo opisane ${ }^{26}$. To istotne w kontekście Trajedyi, ponieważ większość występujących w utworze odwołań do słów „hoc est corpus meum” ma charakter nie tyle swobodnego przekładu, ile nacechowanej interpretacyjnie parafrazy, której kształt każdorazowo umotywowany jest miejscem danego odwołania w strukturze dyskusji i celami argumentacyjnymi. W sumie w tekście wyodrębnić można cztery strategie.

Za pomocą określeń typu „nie rzekł”, „by... nie omieszkał rzec”, „tedy by był rzekł" wprowadzone zostały do utworu parafrazy negatywne, których celem było wskazanie niewłaściwego według autora utworu rozumienia słów Chrystusa. Tak skonstruowane argumenty pozwalały Miłośnikowi Chwały Bożej odrzucić hipotezę, że słowa Chrystusa miałyby być rozumiane literalnie. Przekonuje więc najpierw, że odpowiednia fraza powinna brzmieć odmiennie niż w Biblii, aby oddawać sens zgodny z doktryną o transsubstancjacji:

Miłośnik Chwały Bożej [do Zabobonu]: Sam Krystus Pan uczynić raczył różnicę między chlebem i winem, między ciałem i krwią gdy apostołom mówił: „To jest moje ciało”, ale nie mówił: „To jest sam Krystus”. Także też, podając im kubek z winem: „To jest moja krew”, a nie rzekł: „To jest sam Krystus”. Bo gdyby tak było, jako ty powiedasz, [...] pewnie, żeby był Krystus Pan nie omieszkał rzec: „Bierzcie, to jest cały Krystus”27.

Należy zauważyć, że dosłowne rozumienie tekstu zademonstrowano poprzez parafrazę zawierającą imienne wskazanie na siebie samego, a uniemożliwiającą inną referencję. Tym samym pierwsze bezpośrednie odniesienie do słów Chrystusa w dysputacyjnej części utworu służy utworzeniu możliwej przestrzeni interpretacyjnej poniekąd wbrew intuicji językowej, wedle której zaimek „moje” w oczywisty sposób mógłby odnosić się do podmiotu. Skontrastowanie biblijnych słów z uszczegóławiającą parafrazą ma na celu wywarcie na czytelniku wrażenia, że istnieje alternatywa, której użycie przez Chrystusa wykluczałoby inne sposoby interpretacji. Kryje się za tym rozumowanie, że jeśli takie potencjalne rozwiązanie nie znalazło zastosowania, to w wypadku Syna Bożego nie może być mowy o przypadkowości. W podobnym duchu, pokazując, że istniałoby sformułowanie bardziej

26 Dla przyczynkowych rozpoznań w tym zakresie zob. J. Kamieniecki, Sposoby wykorzystywania Biblii w polemikach religijnych XVI-XVII w., [w:] Inspiracje chrześcijańskie w kulturze Europy. Materiały z konferencji 11-14 maja 1999 r., red. E. Woźniak, t. 1, Łódź 2000, s. 273-282.

27 B. Ochino, Trajedyja o Mszej..., dz. cyt., k. $\mathrm{S}_{6} \mathrm{r}$. 
dosłownie odpowiadające przekonaniom, z którymi podejmował polemikę, starał się Miłośnik zbić argument dotyczący umocowania w Piśmie prawdziwości przeistoczenia:

Miłośnik Chwały Bożej: A gdyćby był miał wolą poświącać temi słowy, tedy by był pewnie rzekł: „To niech będzie moje ciało”, jako ono rzekł, chcąc oczyścić trędowatego: „Bądź oczyścionym”28.

Inne określenie „po prostu rzekł” służy wprowadzeniu cytatu lub bliższej parafrazy słów Chrystusa, a pojawia się w wypowiedzi adwersarza Miłośnika, czyli Zabobonu. „Po prostu” występuje w tekście jako synonimiczne do „właśnie” („właściwie”), przeciwstawiane jest zaś łacińskiemu przysłówkowi „figurate" (czasem używanego w polskim druku w zamiennie z nieklasycznym „figurative”) oznaczającemu sposób mówienia niedosłowny, za pomocą figur myśli ${ }^{29}$. Zabobon korzysta z parafrazy skracającej całość ewangelicznych słów Chrystusa do niedługiego zdania, w którym uwyraźnia się składnia oparta na czasowniku ,jest”. Podkreśla to orzekający tryb konstrukcji, stanowiący tu podstawę do obrony tezy o przeistoczeniu:

Zabobon: Mogłaby to być prawda, kiedy by był Krystus Pan to powiedział figurative, to jest nie właśnie, ale tam $\mathrm{K}<\mathrm{r}>\mathrm{ystus}$ jawnie, jaśnie a po prostu rzekł: „To jest moje ciało, a to jest moja krew”30.

Co do zasady tekstowe wypowiedzi Zabobonu - jako reprezentanta stanowiska rzymskiego - są jednak w utworze Ochina krótsze i zapewnić mają jedynie tyle treści, by Miłośnik wyrażający zapatrywania protestanckie mógł obszernie je zbijać, posługując się liczniejszymi przykładami i bardziej rozbudowaną argumentacją.

Ciekawe, że Miłośnik w tym momencie dyskusji, gdy obszernie wykłada Zabobonowi stosowność odczytywania słów Chrystusa w sensie figuratywnym, po raz pierwszy parafrazuje pozytywnie słowa Chrystusa (tj. nie podaje parafraz ilustrujących niepożądane przezeń interpretacje). Jednak posługuje się w tym celu wprowadzeniem „gdy rzekł”, które przedtem w utworze używane było do przytoczenia cytatu w jego niezniekształconej formie, a także samo

28 Tamże, $\mathrm{k} . \mathrm{Mm}_{3} \mathrm{~V}$.

29 Zob. J. Ziomek, Retoryka opisowa, Wrocław 1990, s. 204-204.

30 B. Ochino, Trajedyja o Mszej..., dz. cyt., k. $\operatorname{Dd}_{1} \mathrm{v}$. 
w sobie znaczeniowo implikuje neutralność i prawdziwość przytaczanych słów, nie sugerując żadnych modyfikacji zastosowanych przez cytującego:

Miłośnik Chwały Bożej: A przetoż i o tych słowiech Pana Krystusowych, które przy swej wieczerzy mówić raczył, ma być rozumiano, bo gdy rzekł: „To jest moje ciało a wino znamionuje krew moję” [...]. Tak wszystko porównawać muszę i chcę cię spytać: może li to być, iż ty słowa Krystus Pan figurate a niewłaśnie mówił? ${ }^{31}$

W rzeczywistości jest to - jak łatwo spostrzec - kontaminacja cytatu z parafrazą. Pierwszy człon stanowi dosłowne przytoczenie wielokrotnie przywoływanych w polemikach słów „hoc est corpus meum”, powielające użycie czasownika ,jest”. Nie dość jednak, że Miłośnik wprowadza w członie drugim czasownik „znamionuje” („oznacza”) zamiast „jest”, to jeszcze całkowicie modyfikuje składnię w stosunku do poprzedniego członu, amplifikując wyjściową frazę o rzeczownik „wino”, umieszczony w pozycji podmiotowej. Nie należałoby zrzucać tego na niechlujność redaktora szesnastowiecznego wydania: ponieważ w tym miejscu Miłośnik po raz pierwszy parafrazuje słowa Chrystusa na rzecz własnej argumentacji, zabieg może być zupełnie celowy: pierwszy człon oddaje bowiem dosłownie emblematyczną frazę o wysokiej frekwencji w różnego rodzaju pismach, nie tylko polemicznych, drugi zaś wprowadza do tej całości komponent interpretacyjny, pokazując mechanizm translacji z języka figuratywnego. Brak komentarza jest ze strony protestanckiego autora sugestią naturalności i oczywistości tej operacji, a w konsekwencji wskazywałoby to na oba człony jako równorzędne, przy czym pierwszy został przytoczony bez zmian, a drugi - już zinterpretowany.

Kolejne parafrazy wskazujące na symboliczne rozumienie Eucharystii Miłośnik będzie opatrywać wprowadzeniami typu ,jakoby tak rzekł”, ,jakoby rzekąc”, jednak dopiero wówczas, gdy obaj dyskutanci określą swoje stanowiska, a interlokutor protestancki wyłoży obszerniej, dlaczego uznaje za zasadne stosowanie wykładnika „repraesentat” (w języku polskim najczęściej za pomocą wyrazu „znamionować”) zamiast „est”:

Miłośnik Chwały Bożej: [Krystus] mówił też figurative a niewłaśnie, ukazując im on chleb, a mówiąc: „To jest moje ciało”, jakoby tak rzekł: „To znamionuje moje ciało”32.

31 Tamże, k. Ee 1 r.

32 Tamże, k. $\mathrm{Ff}_{3} \mathrm{~V}$. 
Miłośnik Chwały Bożej: Gdy tedy rzekł [Krystus]: „To jest moje ciało”, ukazał ciało swoje, jakoby rzekąc: „To ciało figurowane przez chleb jestci moje”, a takżeć też i krew swą ukazał, gdy powiedział: „To jest moja krew”, jakoby tak rzekł: „Ta krew znamionowana przez wino jestci moją krwią"33.

Zagadnienie zostało jednak sproblematyzowane na wcześniejszym etapie dyskusji. Mówienie w sposób figuratywny przedstawione zostało w pierwszej kolejności jako zarzut ze strony Zabobonu, który wytykał Miłośnikowi, że ów rozpoznaje niewłaściwy „modus” w Piśmie Świętym:

Miłośnik Chwały: A tymżeć równie obyczajem Pan a zbawiciel nasz, gdy mówił do apostołów swoich, tegoż zwyczaju w mowie swej używał, gdy rzekł: „To jest ciało moje, a to jest moja krew”, a przedsię im nie dawał ciała ani krwie, jedno chleb a wino. I nie rozumiał tam iście Pan naonczas, iżby on chleb a wino miało być ciałem abo krwią, ale iż on chleb znamionował ciało Jego, a wino znaczyła krew Jego. A jeśliżby Krystus Pan nie był w chlebie ani w winie, tedy każdy ten, który by go w chlebie abo w winie chwalić chciał, wielkie a obrzydłe i nieznośne bałwochwalstwo czyni.

Zabobon: Mogłaby to być prawda, kiedy by był Krystus Pan to powiedział figurative, to jest nie właśnie, ale tam K<r>ystus jawnie, jaśnie a po prostu rzekł: „To jest moje ciało, a to jest moja krew”.

Miłośnik Chwały: I ów ci też mówi jaśnie a po prostu, który stojąc w kościele ukazuje obrazy a mówi: „To jest Krystus, to Piotr, to Paweł”.

Zabobon: Jednoć to my sami między sobą takowego zwyczaju a tego kształtu w mówieniu używamy, ale w innych językoch - tedy nie.

Miłośnik Chwały: I owszem, jakom pierwej powiedział, iż we wszystkich innych językoch daleko więcej tego używają niż w języku polskim, a osobliwie w żydowskim.

Zabobon: Ale Duch Święty tedy nigdziej tym sposobem nie mówi ${ }^{34}$.

Istotą argumentacji Miłośnika w powyższym fragmencie jest odwołanie się do obserwacji na poziomie faktograficznym, do poziomu samych wydarzeń opisywanych przez Pismo. Zwraca uwagę na rozbieżność: Chrystus wskazał na fizyczne przedmioty (niebędące Nim) - chleb oraz wino, wypowiedział zaś słowa, które odnosiły się do Niego. Według Miłośnika, gdy zrekonstruuje się tę scenę, nie może to oznaczać, iż Chrystus mógłby nakazać uczestniczącym w wieczerzy apostołom postrzeganie chleba i wina jako Jego ciała ze względu na kontekst sytuacyjny. Natura argumentacji Miłośnika ma w tym

33 Tamże, k. Gg 7 r-v.

34 Tamże, k. $\operatorname{Dd}_{1} \mathrm{r}-\mathrm{Dd}_{2} \mathrm{r}$. 
wypadku charakter nie terminologiczny, tylko obrazowy - apeluje tym samym do czytelnika o - można by rzec - interpretację zdroworozsądkową, opartą o wyobrażenie sobie przebiegu tego wydarzenia. Zabiegiem, który ma umocnić stanowisko symboliczne, uprzystępniając je tym samym czytelnikowi, jest wprowadzenie retorycznej terminologii dopiero przez oponenta, czyli Zabobon. Ten dopiero powiada, że skutkowałoby to koniecznością uznania słów Chrystusa za figuralne, a nie dosłowne (na co zresztą się nie zgadza). Miłośnik na to rozróżnienie przystaje i będzie się do niego odwoływać w trakcie dyskusji, ale jego podejście do Pisma stawia go w zupełnie innym świetle jako czytelnika i interpretatora Biblii niż reprezentujący stronę rzymską Zabobon. Podobnie jak wielu reformatorów, protestancki bohater Trajedyi wychodzi z założenia, że Pismo jest zrozumiałe, proste i nie wymaga specjalistycznych zabiegów interpretacyjnych opartych o wyrafinowaną terminologię - potrzeba jedynie uważnej lektury.

Na rozpoznanie Zabobonu dotyczące przypisywania Chrystusowi „niewłasnego” (przenośnego) sposobu mówienia Miłośnik zareagował uwagą odnoszącą się do powszechnych zwyczajów językowych. Zauważył, że w wypadku mówienia o wizerunkach nie dochodzi do utożsamienia osoby z jej przedstawieniem, chociaż fraza używana do wyrażenia tej relacji zbudowana została tak samo jak Chrystusowe słowa ustanawiające Eucharystię, w oparciu o wyraz „jest”. Na marginesie warto tu odnotować, że - jak poświadcza spolszczony tekst Ochina - istota protestanckich zarzutów o bałwochwalstwo wobec obrazów nie miała wyłącznie charakteru odnoszącego się do ontologii tychże, gdyż osobność przedstawianego od przedstawiającego ukazano jako kolejny argument „zdroworozsądkowy”35.

Następnie interlokutorzy spierają się o to, w jakich językach mowa figuratywna jest w ogóle używana. Dla Zabobonu to własność języków wernakularnych. Określa je jako te, którymi ludzie posługują się „między sobą”. Domniemywać można, że języki biblijne (hebrajski, grecki) oraz łacina jako

35 Wątek ten zostanie później w Trajedyi rozwinięty: „A gdybych ja tobie ukazał obraz Piotra świętego, a powiedał tobie, iż to jest Piotr święty, któremu było dano klucz królestwa niebieskiego, powiedz, że mi co ty z tej mojej powieści wyrozumiesz. Widzi mi się, iż nic innego nie obaczysz, jedno iż on obraz nic innego nie jest, jedno znamieniem Piotra świętego, któremu były obiecane do nieba klucza” (B. Ochino, Trajedyja o Mszej..., dz. cyt., k. Dd ${ }_{6}$ r). Nt. sporów obrazowych i argumentacji stosowanej przez polskich protestantów zob. więcej: K. Meller, „Pan Krystus po świecie rozesłał nie malarze, ale nauczyciele...”. Gtos polskich pisarzy protestanckich XVI wieku o katolickiej ikonodulii, [w:] Ikonoklazm i ikonofilia. Między historiq a wspótczesnością, red. A. Stankowska, M. Telicki, Poznań 2016, s. 15-34. 
język Wulgaty stanowią inną kategorię. Następnie podaje w wątpliwość, aby Duch Święty używał języka figuratywnego. Sytuacja przedstawiona w utworze staje się zresztą w tym miejscu zawikłana, ponieważ interlokutorzy pragną rozstrzygnąć, czy Duch Święty może mówić figuratywnie, choć wypowiadają się w trakcie procesu przezeń prowadzonego. W swoich wypowiedziach w Trajedyi Duch Święty sam do sprawy się nie odnosi - być może redaktor polskiego wydania uznał, że byłoby to pewne nadużycie nawet w wysoce perswazyjnym tekście. Miłośnik przekonywał jednak, że Duch Święty jako podawca tekstu biblijnego używał różnych figur mowy tak w Starym, jak i Nowym Testamencie („zawżdy figurate a niewłaśnie Duch Święty o nich rozprawował"36).

Wreszcie Miłośnik spotyka się z zarzutem Zabobonu, że parafrazowanie słów Chrystusa stanowi w istocie o pysze interpretatora, który chce „poprawić” pierwotne brzmienie słów wypowiedzianych przez Syna Bożego, jakby Bóg nie potrafił precyzyjnie i jasno wyłożyć kluczowych dla chrześcijan zagadnień:

Zabobon: Dostawa-ć rzecz, a już snadź i nazbyt. A widzę, że ty chcesz być dostateczniejszego rozumu niźli był sam Krystus. Wierz mi, iżci by On to był lepiej umiał powiedzieć niźli ty, a pewnie by to był tylko znak, a nie sama ista rzecz, tedyć by był tak rzekł: „Ten chleb znamionuje ciało moje, a to wino znamionuje krew moję”, ale tu On zgoła a po prostu rzekł: „To jest moje ciało, a to jest moja krew"37.

Odpowiedź Miłośnika odnosi się do tych zarzutów na dwóch poziomach. Po pierwsze, w oparciu o Pismo stara się ukazać, że Chrystus stosował figury myśli w swoich wypowiedziach na przykładach z Mt 23, 14 oraz J 15, 1:

Miłośnik Chwały: Takżeć i Krystus Pan, gdy się nazywał macicą winną i gdy też ono o lucemiernikoch powiedał, iż ony domy wdów pożyrali, tedyć tamo słów takowych nie wykłada jako się właśnie rozumieć mają. A dlategoż każdy krześcijański człowiek, gdy używa sakramentów, tedy nie ma się umysłem a sercem swym zasadzać w znamionach onych, aby tam sobie jakie cuda w nich zmyślać miał, [...] ale wnet ma serce i myśl swoję podnieść wzgórę ku Panu Krystusowi ukrzyżowanemu, którego ony sakramenty znamionują a w którym zawisnęło wszystko dobre nasze i od którego nam pochodzi wszystko zbawienie nasze.

36 B. Ochino, Trajedyja o Mszej..., dz. cyt., k. $\mathrm{Dd}_{8} \mathrm{~V}$.

37 Tamże, k. Kk ${ }_{8} \mathrm{v}$. 
Po drugie jednak, zarzut pychy znieść ma ogólniejsza perspektywa, w której sytuuje się Miłośnik. Przedstawił się jako bezpośrednio nawiązujący do tradycji apostolskiej, stronnictwo papieskie uznał zaś za „nowych” chrześcijan, dalszych od źródeł nauczania Chrystusa i wykrzywiających pierwotny sens Jego nauki. Pod koniec dysputy z Zabobonem określił charakter doktryny o transsubstancjacji poprzez kolejną parafrazę interpretacyjną, tym razem włożoną nie w usta Chrystusa, a samych „rzymian”:

Zabobon: Jako ja słycham o was, tych nowych krześcijanoch, iż wy daleko inaczej słowa Pana Krystusowe odmieniacie, bo gdzie On mówi: „To jest ciało moje”, tedy wy powiedacie, iż to „znamionuje moje ciało”.

Miłośnik Chwały: Zowiesz nas nowymi krześcijany - dalekoście wy sami nowszy. Bo wy, opuściwszy onę pierwszą głowę Krystusa Pana, nowąście nad sobą głowę ustawili człowieka grzechu pełnego [...]. Odrzuciliście tez starodawne nauki, zwyczaje a sprawy apostołów świętych, a jęliście się innych na to miejsce nowych [...], których słowo Boże nigdy nie uczyło [...]. A iż to śmiesz mówić, żebychmy my słowa Pana Krystusowe odmieniać mieli, tedy ja to tobie okażę, żeście wy je daleko inaczej, niźli je On rozumiał, wywrócili, bo gdzie On rzekł: „To jest ciało moje”, to wy mówicie: „W tym jest ciało moje”38.

O czym świadczą zaobserwowane w Trajedyi zabiegi oparte o parafrazowanie tekstu biblijnego? Po pierwsze, wskazać można, że parafraza negatywna wyzyskana została jako wygodny sposób wyrazu dla treści polemicznych. Osłabianie stanowiska przeciwnika poprzez podsumowanie go odpowiednio zmodyfikowanym cytatem biblijnym - mającym ukazać mylne w przekonaniu adwersarzy rozumienie Pisma - to zabieg stosowany w piśmiennictwie. Przywołać można choćby obszerne wyliczenie parafraz słów „Hoc est corpus meum” w Apologii Wargockiego, który w celu uzyskania komicznego efektu i przedstawienia oponentów w niekorzystnym świetle przemieszał faktyczne (mniej lub bardziej adekwatne) parafrazy interpretacyjne rozmaitych reformatorów protestanckich z groteskowymi, np. „Bierzcie i pijcie, ta łyżka jest Nowego Testamentu etc.”39, „To jest ciało moje w niebie siedzące tak daleko od chleba i od nas, jako niebo od ziemie"40. Ze względu jednak na mnogość stanowisk doktrynalnych wśród reformatorów chwyt ten wydaje

38 Tamże, k. Qq $8 \mathrm{v}-\mathrm{Rr}_{1} \mathrm{v}$.

39 A. Wargocki, Apologija przeciwko luteranom, zwinglijanom, kalwinistom, nowokrzczeńcom, Kraków 1605, s. 191.

40 Tamże, s. 196. 
się poręczniejszy dla strony katolickiej. Spolszczenie Ochina pokazuje też odmienne jego wykorzystanie przez protestantów - w toku dyskusji między oponentami w fabularnym, a nie dyskursywnym utworze.

Po drugie, w spolszczeniu Ochina dostrzec można, że parafraza pozytywna jest dla protestanckiego bohatera Trajedyi nie tylko środkiem służącym modulowaniu interpretacji w pożądaną stronę, lecz w zasadzie oddaniem właściwego sensu słów Chrystusa, które wypływa z uwzględnienia kontekstu sytuacyjnego źródła, dekodowaniem przekazu.

Po trzecie, sposoby wprowadzania parafraz cechują różne subtelności. Jej wprowadzanie za pomocą wyrażenia „jakoby rzekł” - choć niepozbawione sugestii przypuszczenia - sprawia, że Chrystus nie przestaje być podmiotem zdania, co zwłaszcza w tak szczególnej dyskusji jak debata eucharystyczna, mającej wszakże ściśle filologiczno-retoryczne korzenie, ma duże znaczenie.

Po czwarte, odnotować należy, że perswazyjny wymiar realizowany jest także w powiązaniu z materialnością drukowanej książki. W tekście polskim (w przeciwieństwie np. do włoskiej i łacińskiej wersji z 1563 roku, w których marginalia referencyjne stanowią podstawę aparatu publikacji) typograficznie zatarte zostały granice cytowania. Druk pozbawiony jest marginaliów wskazujących na konkretne wersety Pisma. Odwołania do Biblii wszyte zostały przez redaktora wydania polskiego w samą tkankę tekstu bez odsłaniania jej jako źródła erudycyjnego. Przedstawiana jest jako słowo Boże, w tym wypadku jako niewątpliwie wypowiedziane słowa Chrystusa. Jako strategia perswazyjna ukazuje ów zabieg integralność znaczeń z ich pierwotnym kontekstem, niejako z pominięciem litery Pisma. Spolszczony utwór Ochina może stać się podstawą do obserwowania na materiale wernakularnym „renesansowego przesunięcia semantycznego”, czyli długotrwałego procesu przemian semantyki z charakterystycznego dla średniowiecza oczywistego powiązania między res a verba do nowożytnego paradygmatu rozpoznającego „uwikłanie języka w kontekst i zawsze skonkretyzowane użycie”41. Wiąże się to z dopuszczeniem możliwości, że tekst biblijny miewa charakter retoryczny, a w konsekwencji także zapisane w Piśmie słowa Chrystusa mogą być ukształtowane według zasad retoryki klasycznej i jak w tym przypadku, stanowić figurę myśli.

Po piąte wreszcie, ułatwia osadzenie „nowej semantyki” w Trajedyi brak powiązania przytaczanych słów z konkretnym przekładem (choć należy także

41 W. Ryczek, Renesansowe teorie figuratywności: Peter Schade (Petrus Mosellanus), „Pamiętnik Literacki” 104 (2013) z. 3, s. 160 . Zob. także: R. Waswo, Language and Meaning in the Renaissance, Princeton 1987, s. 48-81. 
odnotować, że opracowywany przez środowisko ewangelickie przekład brzeski nie był jeszcze wówczas ukończony). Pozwala to rozłożyć akcenty zależnie od bieżącej potrzeby polemicznej (w tym wypadku: est, significat), podczas gdy inne szczegóły w innych sytuacjach będące powodem zażartego sporu (jak np. kwestia oddawania w polszczyźnie słowa „calix”, które w Trajedyi występuje naprzemiennie i jako „kubek”, i jako „kielich”) ${ }^{42}$ nie odgrywają tutaj większego znaczenia.

\section{Abstrakt \\ Parafraza jako środek polemiczny w dyskusji eucharystycznej w „Trajedyi o Mszej” (1560) Bernardina Ochina}

Celem artykułu jest omówienie sposobów wykorzystywania biblijnych słów Chrystusa „hoc est corpus meum” w spolszczonym utworze Ochina wydanym w Pińczowie w roku 1560. Po pierwsze, omówiony zostaje kontekst przygotowania i wydania spolszczenia utworu (niedawna śmierć Jana Łaskiego, cele stawiane przez środowisko małopolskich ewangelików). Po drugie, przeanalizowane zostaną metody i warunki wprowadzania parafraz do tekstu utworu, które świadczą tak o potencjale perswazyjno-edukacyjnym omawianego utworu, jak i ogólniejszej perspektywie wczesnonowożytnych zmian semantycznych przejawiających się w dyskusjach o charakterze teologicznym prowadzonych w języku wernakularnym.

Słowa kluczowe: Eucharystia, liturgia, ceremonie, reformacja, polemiki, Francesco Lismanino, Lismanini

\section{Abstract}

\section{Paraphrase as a Tool of Polemics in the Discussion on the Eucharist in Bernardino Ochino's "Trajedyja o Mszej" [Tragedy on Mass] (1560)}

The aim of this article is to discuss the ways in which Christ's Biblical words "hoc est corpus meum" are used in Ochino's translated text, which was published in Pińczów in 1560. First, the context of the preparation and Polish translation of the work (the recent death of Jan Łaski and the aims of the Lutheran community in Lesser Poland) are discussed. Next, the methods and conditions for the introduction of paraphrases in texts in the work, which attest both to the persuasive and educational as well as more

42 D. Frick, Polska philologia sacra $w$ czasach reformacji $i$ kontrreformacji. Kilka kart $z$ historii sporów wyznaniowych (1551-1632), przeł. K. Szymańska, Warszawa 2018, s. 164 zasugerował, że implikujący prostotę wyraz „kubek” charakterystyczny był dla tłumaczeń protestanckich, podczas gdy katolicy preferowali tłumaczenie „kielich”. Wywołało to zresztą dyskusję później między Marcinem Czechowicem (Plastr na wydanie Nowego Testamentu, [Kraków 1594], s. 38) a Marcinem Łaszczem (Recepta na plastra Czechowica, ministra nowokrzczeńskiego, Kraków 1597, s. 44-50). Drugi wytykał wulgaryzację tego słowa antytrynitarzom, mówiąc nie o postulowanym przez nich „kubku”, a - w celu ośmieszenia - „kuflu”). 
general perspective of early modern semantic changes appearing in theological discussions in vernacular languages, are subject to analysis.

Keywords: Eucharist, liturgy, ceremony, Reformation, polemics, Francesco Lismanino, Lismanini

\section{References}

Allen, M. (2015). Sacraments in the Reformed and Anglican Reformation (H. Boersma \& M. Levering, Eds.). Oxford University Press. https://doi.org/10.1093/oxfordhb/9780199659067.013.35

Boguniowski, J. W. (2001). Rozwój historyczny ksiag liturgii rzymskiej do soboru trydenckiego i ich recepcja w Polsce. Wydawnictwo UNUM.

Burnett, A. N. (2016). From concord to confession: The Wittenberg Concord and the Consensus Tigurinus in historical perspective. Reformation \& Renaissance Review, 18(1), 47-58. https://doi.org/10.1080/14622459. 2016.1157347

Caccamo, D. (1970). Eretici italiani in Moravia, Polonia, Transilvania 1558-1611. Studi e documenti. G. C. Sansoni.

Czechowic, M. (1594). Plastr na wydanie Nowego Testamentu przez x. Jakuba Wujka. Aleksy Rodecki.

Estreicher, K. (1930). Bibliografia polska (Vol. 28). Polska Akademia Umiejętności.

Estreicher, K. (1933). Bibliografia polska (Vol. 29). Polska Akademia Umiejętności.

Frick, D. A. (2018). Polska philologia sacra w czasach reformacji i kontrreformacji. Kilka kart z historii sporów wyznaniowych (1551-1632) (K. Szymańska, Trans.). Wydział Polonistyki Uniwersytetu Warszawskiego.

Gmiterek, H. (2001). Jan Łaski a unia Małopolan z braćmi czeskimi. In P. Salwa \& W. Kriegseisen (Eds.), Jan Łaski 1499-1560 w pięćsetlecie urodzin. Materiały konferencji zorganizowanej przez Instytut Historii PAN, Uniwersytet Warszawski oraz Konsystorz Kościoła Ewangelicko-Reformowanego w RP. Wydawnictwo Naukowe Semper.

Kamieniecki, J. (2000). Sposoby wykorzystywania Biblii w polemikach religijnych XVI-XVII w. In E. Woźniak (Ed.), Inspiracje chrześcijańskie w kulturze Europy. Materiały z konferencji 11-14 maja 1999 r. (Vol. 1, pp. 273-282). Archidiecezjalne Wydawnictwo Łódzkie.

Kleiner, J. (1910). „Tragedye” Ochina. Pamiętnik Literacki, 9(4), 397-418.

Kordyzon, W. (2019). Msza przed trybunałem. Personifikacja Mszy w spolszczonym dialogu Bernardina Ochina na tle europejskiej literatury reformacyjnej pierwszej połowy XVI wieku. Terminus, 21(2), 215-244. https:// doi.org/10.4467/20843844TE.19.017.11191

Kowalska, H. (1999). Dziatalność reformatorska Jana Łaskiego w Polsce 1556-1560. Neriton.

Łaski, J. (2004). Forma i całkowity porządek kościelnego postugiwania (T. Płóciennik, Trans.). Semper.

Łaszcz, M. (1597). Recepta na plastr Czechowica ministra nowokrzczeńskiego [...]. Drukarnia Łazarzowa.

Meller, K. (2016). „Pan Krystus po świecie rozesłał nie malarze, ale nauczyciele...”. Głos polskich pisarzy protestanckich XVI wieku o katolickiej ikonodulii. In A. Stankowska \& M. Telicki (Eds.), Ikonoklazm i ikonofilia. Między historią a wspótczesnościa (pp. 15-34). Wydawnictwo Poznańskiego Towarzystwa Przyjaciół Nauk. Nelson Burnett, A. (2011). Karlstadt and the Origins of the Eucharistic Controversy. A Study in the Circulation of Ideas. Oxford University Press. https://doi.org/10.1093/acprof:oso/9780199753994.001.0001

Ochino, B. (1560). Trajedyja o Mszej, z której każdy snadnie wyrozumieć może początek i wszelaka jej sprawę, i co prawdziwej Wieczerzej Pańskiej właśnie każdy wiedzieć ma. Daniel z Łęczycy.

Ogonowski, Z. (2015). Socynianizm. Dzieje, poglady, oddziaływanie. Instytut Historii Nauki im. Ludwika i Aleksandra Birkenmajerów Polskiej Akademii Nauk, Oficyna Wydawnicza ASPRA-JR.

Petkūnas, D. (2007). Holy Communion rites in the Polish and Lithuanian Reformed Agendas of the 16th and early 17th centuries. Klaipèdos Univ. Leidykla.

Ryczek, W. (2013). Renesansowe teorie figuratywności: Peter Schade (Petrus Mosellanus). Pamiętnik Literacki, 104(3), 153-172. 
Ryszka-Kurczab, M. (2018). „Aby każdy miłośnik prawdy onej szukając, z czytania jej dojść mógł”. Sposoby uwiarygodniania przekazu w szesnastowiecznych relacjach z polskich dysput wyznaniowych. Terminus, 20(2), 165-193. https://doi.org/10.4467/20843844TE.18.006.9751

Sczaniecki, P. (1966). Stużba Boża w dawnej Polsce. Księgarnia św. Wojciecha.

Silvius, A. (1560). Oratio funebris in obitum praeclarissimi viri et veare religionis vindicis invictissimi, Domini Ioannis a Lasco. Officina Danielis Lancicij.

Sipayłło, M. (Ed.). (1966). Akta synodów różnowierczych w Polsce: Vol. 1: 1550-1559. Wydawnictwa Uniwersytetu Warszawskiego.

Ślaski, J. (1974). Le „Tragedie” di Bernardino Ochino in polacco. In Movimenti ereticali in Italia e in Polonia nei secoli XVI-XVII. Atti del Convegno italopolacco, Firenze, 22-24 settembre 1971 (pp. 103-117). Istituto Nazionale di Studi sul Rinascimento.

Statorius, P. (1560a). In clarissimi viri d[omini] Ioannis a Lasko Poloniae baronis obitum funebris oratio. Officina Danielis Lancicij.

Statorius, P. (1560b). In duos Martini Cromeri dialogos, qui de vera et falsa nostri temporis religion inscribuntur animadversiones brevissimae. Officina Danielis Lancicij.

Wanner, V. (1559). Praktyka o mszy, co o niej a jako rozumieć mamy (W. Nowomiejski, Trans.). Hans Daubmann. Wargocki, A. (1605). Apologija przeciwko luteranom, zwinglijanom, kalwinistom, nowokrzczeńcom. Jakub Siebeneicher.

Waswo, R. (1987). Language and Meaning in the Renaissance. Princeton University Press.

Winiarska-Górska, I. (2010). Zagadnienie ceremonii w szesnasto- i siedemnastowiecznym piśmiennictwie religijnym protestantów jako spór o język sakralny. Napis, 16, 59-76.

Wotschke, T. (1908). Der Briefwechsel der Schweizer mit den Polen. M. Heinsius Nachf.

Ziomek, J. (1990). Retoryka opisowa. Zakład Narodowy im. Ossolińskich - Wydawnictwo. 